Open Access

\title{
Resources, experience, and perseverance in entrepreneurs' perceived likelihood of success in an emerging economy
}

\author{
Quan Hoang Vuong ${ }^{1 *}$, Thu Hang Do ${ }^{2}$ and Thu Trang Vuong ${ }^{2}$
}

\footnotetext{
* Correspondence: qvuong@ulb.ac.be ${ }^{1}$ Centre Emile Bernheim, Université Libre de Bruxelles, 50 Ave. F.D. Roosevelt, Brussels 1050, Belgium Full list of author information is available at the end of the article
}

\begin{abstract}
This paper introduces new results obtained from a statistical investigation into a 3071-observation data set collected from a Vietnamese nationwide entrepreneurship survey. From established relationships, such factors as preparedness, financial resources, and participation in social networks are confirmed to have significant effects on entrepreneurial decisions. Entrepreneurs, both financially constrained and unconstrained, who have a business plan tend to start their entrepreneurial ventures earlier. Also, financial constraints have a profound impact on the entrepreneurial decisions. When perceiving the likelihood of success to be high, an entrepreneur shows the tendency for prompt action on business ideas. But when seeing the risk of prolonging the waiting time to first revenue, a prospective entrepreneur would be more likely to wait for more favorable conditions despite the vagueness of "favorable." Additionally, empirical computations indicate that there is a $41.3 \%$ probability that an extant entrepreneur who is generating revenue sees high chance of success. Past work and entrepreneurial experiences also have positive impacts on both the entrepreneurial decisions and perceived chance of success.
\end{abstract}

Keyword: Entrepreneurship, New venture, Transitional economies

JEL classification: L26, M13, P27

\section{Background}

Entrepreneurship has been forming an integral part of the world's economy for hundreds of years now, and the process is described by Schumpeter (1934) as "a perennial gale of creative destruction." The literature on entrepreneurship is very large and diverse, both on developed and developing economies. Nonetheless, empirical studies on entrepreneurship in an emerging economy like Vietnam still fall short of demand as far as policy making and the public understanding are concerned.

This paper aims to communicate new empirical results from research on relationships between the critical factors of resources, work/entrepreneurial experiences, perseverance of Vietnamese entrepreneurs and the likelihood of success, and decisions on their own entrepreneurial attempts, using a nationwide survey data set containing more than 3000 observations obtained in 2015 (Fig. 1).

The paper has four main parts. It begins with a brief literature review examining key variables in subsequent modeling efforts. The next part presents relevant research 


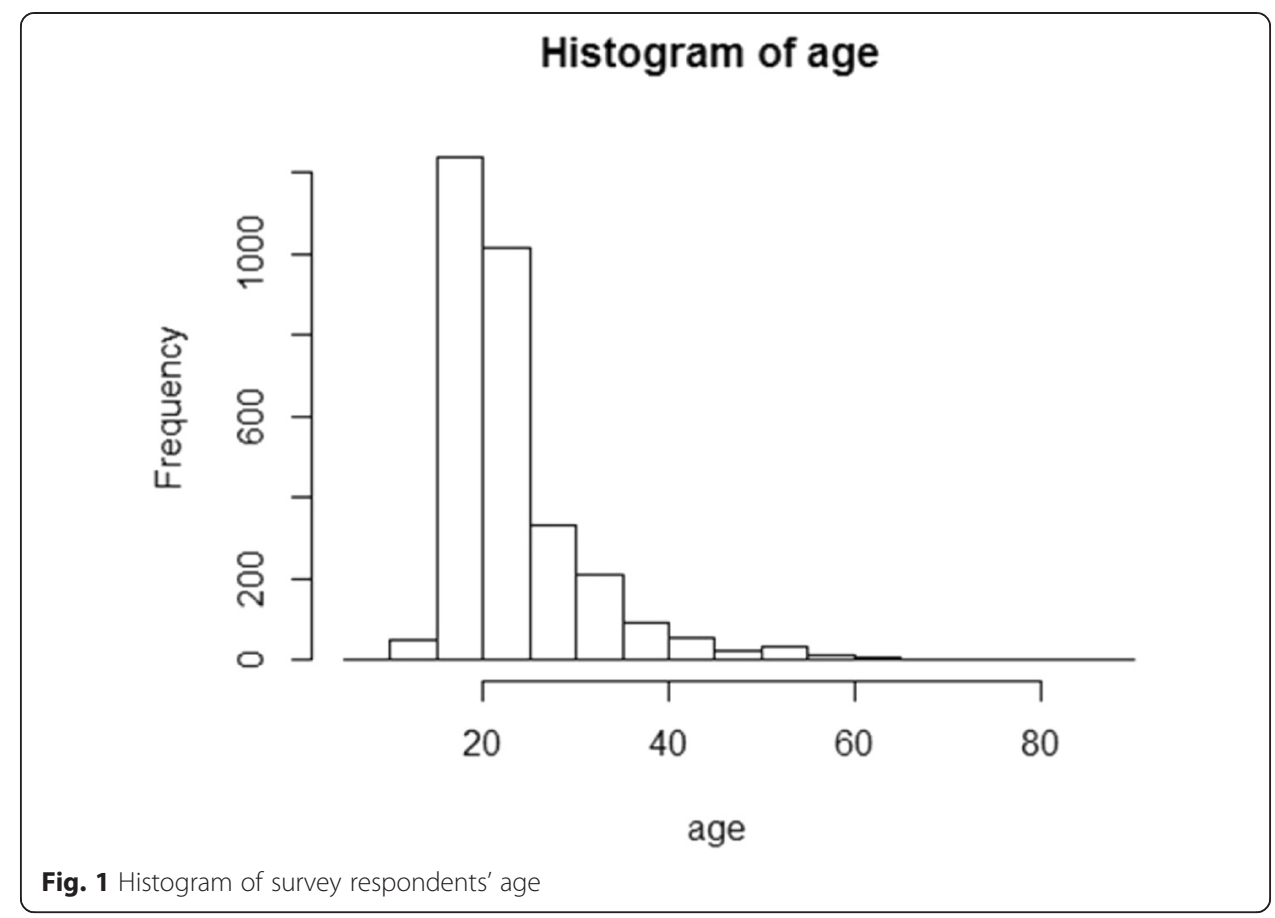

questions and the statistical model employed in investigating them. Third, the paper describes the data set and analysis. The article closes with a discussion of key insights and implications.

The research serves as one of the first major attempts employing data modeling and statistical analysis to investigate the far-reaching impacts of a nationwide socioeconomic phenomenon in the transition economy of Vietnam. The research approach adopted in this investigation represents a combination of a real-world and direct data survey on the target group of extant and prospective entrepreneurs. Its modeling efforts are made following multi-category discrete data procedures for both detecting and confirming possible theoretical effects of factors and their associated categorical variables. Previously verified efficiency and effectiveness of adopting this empirical strategy and yielding insightful results from an emerging market economy serve to be the cornerstone for leveraging practice-surveying experiences and laborious research study in this growing field of research. Plus, Vietnam's fast-growing GDP of $6.68 \%$ in 2015 together with 90,000 firms being newly created in 2015 alone presents an ample opportunity for further investigation into this particularly fascinating economic sector in the coming years.

The study is both novel and original as so far there has been lack of empirical studies, in the ASEAN region in general and Vietnam in particular, for gaining better insights into the entrepreneurship system although it has for at least three decades now been one of the key economic pillars for this fast-growing region of the world to rest on. The dynamism of the ASEAN region and Vietnam is expected to be based on the determination and aspiration of almost 33 million younger people having the tendency of and being oriented to act as entrepreneurs. Despite its increasing importance, public understanding, entrepreneurs' included, and the policy-making process in Vietnam have so far faced a non-trivial shortage, which oftentimes leads to either illusions among prospective, and to some extent even extant, entrepreneurs or inefficiencies of government-funded 
entrepreneurship-promotion programs and their associated measures. Without truly useful insights gained from real-world data analysis and empirical confirmatory exercises, the risks for society at large in such nationwide economic trends will tend to be elevated. Knowledge and insights that help contain the rising risks offer an immeasurable value to the economic development course in the long run especially when and where resources are considered scarce. Socially speaking, they bring about immediate policy implications, such as where the time, efforts, and financial resources should be spent or how the functions of government agencies involved in development of entrepreneurship should be aligned and coordinated effectively and many more.

From another angle, the research attempt and its results will significantly contribute to the scientific literature, as, so far in the region, there has been a lack of studies that can empirically connect economic happenings with sociopsychological elements prevailing in society, and this study showcases that type of connection. In addition, the laborious work of computing conditional probabilities as presented in the main part of analysis has yielded specific and practical understandings about under which conditions a particular response of primary concern will take place. And this knowledge is critically important to both extant literature and possible identification of novel hypothetical concepts. Like any other studies, this article has a number of limitations, which will be discussed at the end of the paper.

\section{A brief literature review}

The extant literature on entrepreneurship is immense, and given the main purpose of quickly communicating new results, this section concentrates mainly on (a) providing relevant insights and knowledge on entrepreneurial attitudes that may govern their behaviors in entrepreneurial attempts and some typical environmental factors that affect their attitudes and behaviors. They all together help characterize our "typical entrepreneur" both as object and subject in the socioeconomic phenomenon of entrepreneurship and (b) a group of factors viewed as foundations to entrepreneurial intention, preparation, and implementation.

\section{Entrepreneurial attitudes and environmental factors that affect entrepreneurs}

A score of research studies have been focused on examining the entrepreneurial attitudes through different settings of entrepreneurial attitudes/orientations, mostly among the youths and students, such as those of Harris and Gibson (2008), Walstad and Kourilsky (1998), Zampetakis et al. (2009), and Souitaris et al. (2007). These research efforts seek to learn about relationships between potential business achievement and innovation, perceived control of outcomes, and even self-esteem in business; part of these attempts also take into account entrepreneurs' demographic data and past entrepreneurial experience. The results, empirical and experimental, agree on the fact that possession of entrepreneurial attitudes is quite common among the youths and students, and depending on specific personalities, entrepreneurial experience is found to be associated with one category of attitude or another. Those with family business experience tend to possess more developed entrepreneurial attitudes and self-efficacy (Walstad and Kourilsky 1998; Valliere 2006). Those with stronger attitudes tend to show better performance (Trevelyan 2009; Turker and Sonmez, 2009). 
Training and education programs help provide the opportunity for direct entrepreneurial exposures to disadvantaged groups of youth (Walstad and Kourilsky 1998; Fayolle and Gailly 2015).

The literature also shows that potential and strong interests in entrepreneurship do not necessarily result in specific tendencies to pursue entrepreneurial ventures (Walstad and Kourilsky 1998; Fayolle and Gailly 2015), suggesting that education background and exposure to training programs have profound impacts on both orientations and understanding of competitive market mechanisms (Walstad and Kourilsky 1998; Harris and Gibson 2008). Both training and education background and past business experience contribute to shaping prospective entrepreneurs' orientations and attitudes through the development of their emotional intelligence (Harrison \& Huntington 2000; Souitaris et al. 2007; Harris and Gibson 2008; Zampetakis et al. 2009; Fayolle and Gailly 2015). Krueger (1993) and Zampetakis et al. (2009) also suggest that for better understanding the motivation and making efficient policy encouraging entrepreneurship, educators and policy makers need further empirical evidence, and practical implications, from real-world surveys.

A generally accepted knowledge holds that psychological and environmental factors both contribute to the success of the entrepreneurial endeavor. Brockhaus (1980) is among the first researchers to provide theoretical verification for this. From his classic work, the public, professionals, and entrepreneurship scholars have appreciated the role psychological and environmental factors play in encouraging or discouraging the development of entrepreneurship in societies and the course of development. This important understanding has later been elaborated with subsequent influential research such as that of Kuratko et al. (1990) with a keen eye on the cultures, growth orientations, and ideation. In addition, environmental factors such as societies and government-finance programs, including entrepreneurship education initiatives, show positive effect on the development of entrepreneurship in general and improved awareness among prospective entrepreneurs in particular (Krueger 1993; Lerner et al. 1997; Harris et al. 2015). From another aspect, Lerner et al. (1997) and Valliere (2006) provide economic evidence showing that growth and prospects have significant effects on the risk-reward nexus and nature of costs as perceived by entrepreneurs, thus affecting their behaviors accordingly. Trevelyan (2009) agrees with this and advances the implication with longitudinal data suggesting the resulting entrepreneurial attitudes affect entrepreneurs' action and positions in new venture development. Nonetheless, it is not obvious that environmental influences create a significant impact on both entrepreneurial ventures' performance and attitudes, as in specific spaces, time periods, and contexts, expected impacts may not have been verified by empirical data, as pointed in Solymossy (1998).

Given the complexity and diversity of issues, hypotheses, and results regarding entrepreneurship research, the subsequent discussion is focused on the necessity and emerging issues relating to our hypotheses, variables to be considered, and the analysis that follows. The presentation is divided into groups of issues and aspects that give rise to hypotheses and corresponding research questions.

\section{The issues of entrepreneurs' preparedness, resources, social networks, and perceived chance of survival}

Although the decision to become an entrepreneur requires an entrepreneurial selfefficacy construct, in line with Chen et al. (1998), the entrepreneurial experiences are 
oftentimes the harsh realities, and failures are almost unavoidable for the novice (Bosma et al. 2009; Cope 2011; Baron, Franklin, \& Hmieleski, 2013; Vuong and Napier 2014). Having learned from failures helps improve entrepreneurs' preparedness and confidence. Chen et al. (2009) suggest that entrepreneurs do their "homework" and do it well as this is perhaps the best way to persuade investors that the entrepreneurs are prepared and poised. The factor of preparedness is more complex than often thought about as at least three perspectives (namely, entrepreneurial, organizational, and ecological) have been identified in earlier discussions of entrepreneurship theory (Van de Ven et al. 1984). In addition, because an entrepreneurial self-efficacy construct consists of such factors as innovation, marketing, management, risk taking, and financial controls, an entrepreneur's preparedness becomes more challenging than a mere self-confidence and personal motivation.

It is well known that capital and resources are critical to entrepreneurial decisions in the start-up phase. Family and relatives and friends and social networks' peers are an integral part of the game (Chang et al. 2009; Zahra et al. 2008) as the social relationship offers further legitimacy to new venture (Meyer and Rowan 1977; Hannan and Freeman 1984; Nagy et al. 2012). The emerging trend of crowdfunding further emphasizes the traditional factors (Brown 1993; Mollick 2014) most probably due the fact that entrepreneurs and new ventures will likely need to present their credentials to gradually gain credibility (Hannan and Freeman 1984). Credentials play very important roles in the process of granting resources in the early stages of the entrepreneurship (Hallen and Eisenhardt 2012; Nagy et al. 2012; Vuong and Napier 2014). In addition, the acquiring of resources for entrepreneurial endeavors has become even more complex because for entrepreneurs relationship development and resource exchange are a bidirectional process (Weerawardena and Mort 2006; Huang and Knight 2015).

Due to the difficulty of attaining optimal conditions for the above aspects of entrepreneurship, resilience is something desirable but hard to achieve for entrepreneurs (Sullivan-Taylor and Branicki 2011), and entrepreneurship is even regarded as an "extreme" experience (Schindehutte et al. 2006). Although resources are critically important in constituting the overall strength of an entrepreneurial venture, the resource-acquiring game can become dangerous too. There is evidence demonstrating the effect of "destructive creation" where and when an overemphasis on resources is coupled with increasing costs of amassing resources and persistent lack of innovation capacity, leading a venture to constantly declining efficiency and finally financial distress (Vuong and Napier 2014).

\section{Work and entrepreneurial experiences, perseverance, and expected time lag to first revenue}

It is known that complication arises from the entrepreneurial process perceived as both increasing risks and unexpected challenges (Santos et al. 2013; Huang and Knight 2015). Therefore, entrepreneurial experience and self-efficacy becomes critical for an entrepreneur to improve both risk appetite and skills to implement his/her entrepreneurship plan (Hallak et al. 2011; Fayolle and Gailly 2015). In the age of complex technological innovations and rising competition, the time taken to first sale tends to be lengthened due to complex processes (Schoonhoven et al. 1990). Thus, stronger commitment is required (Zahra et al. 2008). 
While passion plays a limited role in shaping investor decision-making (Chen et al. 2009), the perseverance of entrepreneurs has become a determining factor, and it is not easy to maintain perseverance due to rising pressure of work-life experiences and lack of coping strategies (Jennings and McDougald 2007; Santos et al. 2013). Unfortunately, perseverance and self-efficacy are not costless (Markman et al. 2005). Westhead et al. (2009) provide empirical evidence on habitual entrepreneurs' capability of identifying more business opportunities than the novice, thanks in part to higher information search intensity.

Brush et al. (2008) argue that assembling different types of resources is closely related to the likelihood of first sale. However, higher aspiration of resources is not necessarily associated with achievement of sales but rather related to ambitions (Bosma et al. 2009). The determining of early strategic tasks thus becomes both difficult and critical while not many entrepreneurs believe in the value of their "homework" such as preparing a best available business plan (Davidsson 2006; Vuong and Napier 2015). Even the value of formation of entrepreneurial teams - which is key to sustained growth-is not obvious (Vyakarnam et al. 1999).

According Wagner (2007), "nascent" entrepreneurship is even more elusive as "less is known about precisely what nascent entrepreneurs are doing and about the timing of the activities." That is why early planning is so important (Dimov 2010; Vuong and Napier 2015). In Dimov's (2010) evidence from the Panel Study of Entrepreneurial Dynamics (PSED) data, both entrepreneurial experience and early planning have indirect effects on venture emergence. In an earlier empirical study, Kessler and Frank (2009) look into the "influencing dimensions" (the entrepreneur, resources, the environment, and the process) to confirm the strongest influence of past experience and process, which are closely connected to skills and perseverance, on success.

The brief review of the literature on entrepreneurship helps to (i) learn about the relevance of factors that enter our subsequent analysis of survey data; (ii) explore possible relationships and directions of impacts on determination of entrepreneurial pursuits and chance of success/survival; and (iii) have an idea about which factors should be emphasized in an emerging economy context. These considerations are reflected in the next statement of research questions.

\section{Research questions and analytical framework}

\section{Research questions}

RQ1: How entrepreneurs' preparedness (e.g., having a business plan), financial resource limitation, and participation in social networks of entrepreneurs impact their decisions in making entrepreneurial attempts?

RQ2: Do self-perceived likelihood of business survival/success and expected time to the first revenue generation affect entrepreneurial decision on creating a business? RQ3: How do past work experiences and past entrepreneurial attempts impact entrepreneurs' expectation of their waiting time to the first revenue? RQ4: What are the joint impacts of resources, past entrepreneurial attempts, and perseverance on self-assessment of time to the first revenue for entrepreneurs with financial constraints? Is there any difference between those with and without financial constraints? 
The BCL method

Our investigation of the likely effects of the predictor (independent) variables on entrepreneurship outcomes employs the analytical framework of baseline-category logits (BCL). The BCL modeling with a full description of its technical treatments are provided in Agresti (2013). Below, we present key ideas of the framework and the way impacts of independent variables on responses are investigated.

The BCL method is estimated as a multivariate generalized linear model (GLM) taking the form

$$
\mathbf{g}\left(\boldsymbol{\mu}_{i}\right)=\mathbf{X}_{i} \boldsymbol{\beta}
$$

where $\boldsymbol{\mu}_{i}=\mathrm{E}\left(\mathbf{Y}_{i}\right)$, corresponding to $\mathbf{y}_{i}=\left(y_{i 1}, y_{i 2}, \ldots\right)^{\prime}$; row $h$ of the model matrix $\mathrm{X}_{i}$ for observation $i$ contains values of independent variables for $y_{i h}$.

Following this method, as $\pi_{j}(\mathbf{x})=P(Y=j \mid \mathbf{x})$ represent a fixed setting for predictor variables, with $\sum_{j} \pi_{j}(\mathbf{x})=1$, count data are distributed over $J$ categories of $Y$ as multinomial with corresponding probabilities $\left\{\pi_{1}(\mathbf{x}), \ldots, \pi_{j}(\mathbf{x})\right\}$. The BCL model aligns each response (dependent) variable with a baseline category: $\ln \left[\pi_{j}(\mathbf{x}) / \boldsymbol{\pi}_{J}(\mathbf{x})\right]$, with $j=1, \ldots$, $J-1$.

As $\ln \left[\boldsymbol{\pi}_{a}(\mathbf{x}) / \boldsymbol{\pi}_{b}(\mathbf{x})\right]=\ln \left[\boldsymbol{\pi}_{a}(\mathbf{x}) / \boldsymbol{\pi}_{J}(\mathbf{x})\right]-\ln \left[\boldsymbol{\pi}_{b}(\mathbf{x}) / \boldsymbol{\pi}_{J}(\mathbf{x})\right]$, the set of response probabilities from multinomial logits $\left\{\boldsymbol{\pi}_{j}(\mathbf{x})\right\}$ can be computed from the formula

$$
\boldsymbol{\pi}_{j}(\mathbf{x})=\frac{\exp \left(\alpha_{j}+\beta_{j}^{\mathrm{T}} \mathbf{x}\right)}{1+\sum_{h}^{J-1} \exp \left(\alpha_{h}+\beta_{h}^{\mathrm{T}} \mathbf{x}\right)}
$$

The categorical variables reflecting the nature of our survey data are both dichotomous (e.g., the variable of the entrepreneur's perseverance for this entrepreneurial attempt "tforstart" takes value of "g24" or "less24") and multinomial, for example, factor "tot1strev" representing the time lag to the first revenue from business conduct, which takes values of "now" (currently generating revenues), "soon" (expecting to generate revenues within 12 months), or "notsure" (uncertain about future date when revenues are generated). Their coded names and values are described in the corresponding data set in the data section. A relevant example of actual applications of the BCL modeling with survey data is given in Vuong (2015).

\section{Data, estimations, and results \\ Data}

The survey was conducted through a series of entrepreneurs' meetings that were organized in five economic centers in Vietnam (Hanoi, Ho Chi Minh City, Da Nang, Buon Ma Thuot, Can Tho) by the Vietnamese Youth Federation, Trung Nguyen Coffee Group, and the Center for Business Study and Assistance under a joint initiative on youth entrepreneurship. The raw data, from which processed data sets are derived, is introduced and deposited in Vuong (2016). Entrepreneur participants who were willing to join the survey were explained about the purpose and how to complete the questionnaire given by authorized personnel. Answers were collected at the end of the each event. Figure 2 describes the overall response to questions about entrepreneurs' anticipated capital mobilization and expected revenue (all in logarithmic scale). 


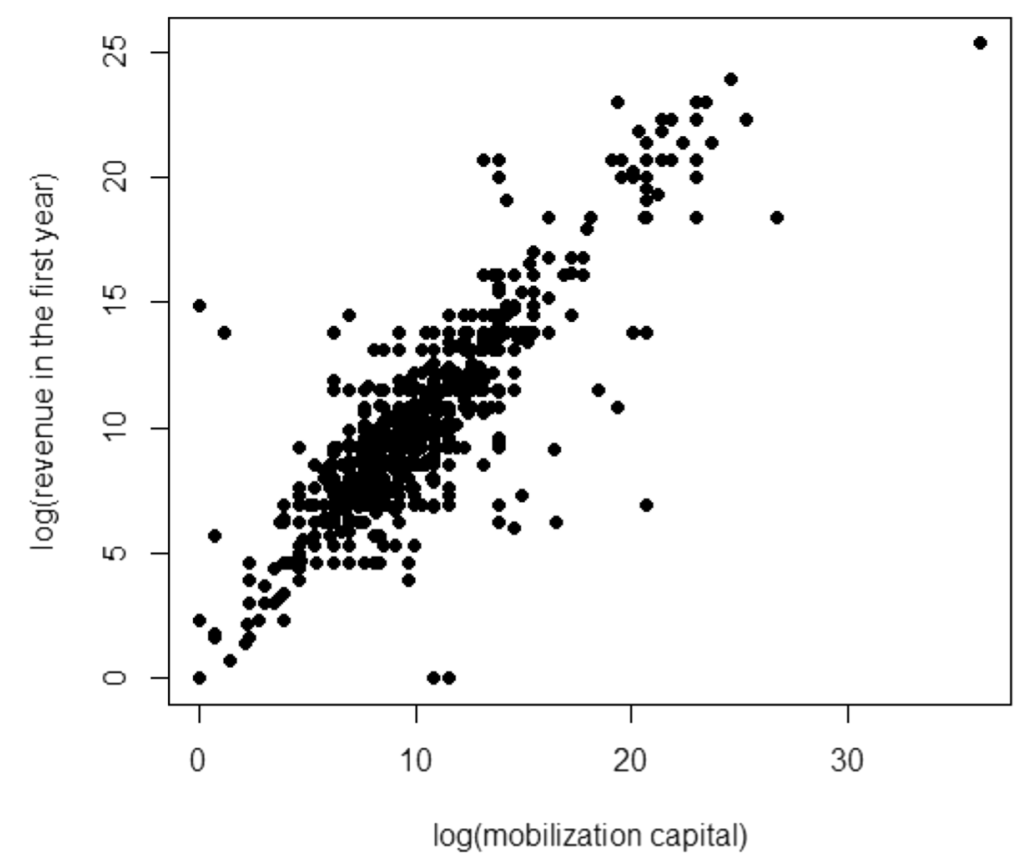

Fig. 2 Highly possible relationship between anticipated capital consumption and revenues

Among the estimated number of 50,000 entrepreneurs who attended these events, the survey team randomly approached about 10,000 during the survey period, from March to May 2015, and was able to collect a random data sample containing 3071 observations, representing answers in full or in part. In our subsequent analysis, each data set requires a specific structure reflected through the corresponding tabulated form, with the number of observations used varying depending upon appropriate treatments for missing data (for partial answers). The data are categorical by both research nature and design, with Fig. 3 presenting the count data of responses to the question about which source of finance the entrepreneur counts on.

\section{Data for RQ1}

For this first data set, $N=2524$.

\begin{tabular}{|c|c|c|}
\hline Factors & Categories & Remarks \\
\hline "member" & $\begin{array}{l}\cdot \text { "no" } \\
\cdot \text { •"yes" }\end{array}$ & Independent dichotomous variables. \\
\hline "plan" & $\begin{array}{l}\cdot \text { "noneed" } \\
\cdot \text { "inprocess" } \\
\text { - "basic" } \\
\cdot \text { "good" }\end{array}$ & $\begin{array}{l}\text { Independent polytomous variables. The variables take one of these four categorical } \\
\text { values, of which: "noneed": an entrepreneur does not think he/she would need a } \\
\text { business plan; "inprocess": a business plan for their venture is being prepared; "basic": } \\
\text { a basic plan is available; and "good": the entrepreneur has a well-prepared plan for } \\
\text { his venture. }\end{array}$ \\
\hline "finance" & $\begin{array}{l}\cdot \text { "noshort" } \\
\cdot \text { "shortage" }\end{array}$ & $\begin{array}{l}\text { Independent dichotomous variable that indicates if the entrepreneur faces financial } \\
\text { constraint ("shortage") or not ("noshort"). }\end{array}$ \\
\hline "startplan" & $\begin{array}{l}\cdot \text { "a" } \\
\cdot \text { "b" } \\
\cdot \text { "c" } \\
\cdot \text { "d" }\end{array}$ & $\begin{array}{l}\text { Dependent polytomous variables, which capture responses if the entrepreneur is } \\
\text { currently operating a venture ("a"); starting soon }(" \mathrm{~b} \text { "); only starting upon favorable } \\
\text { socioeconomic conditions ("c"); ; or not starting any business (" } d \text { "). }\end{array}$ \\
\hline
\end{tabular}




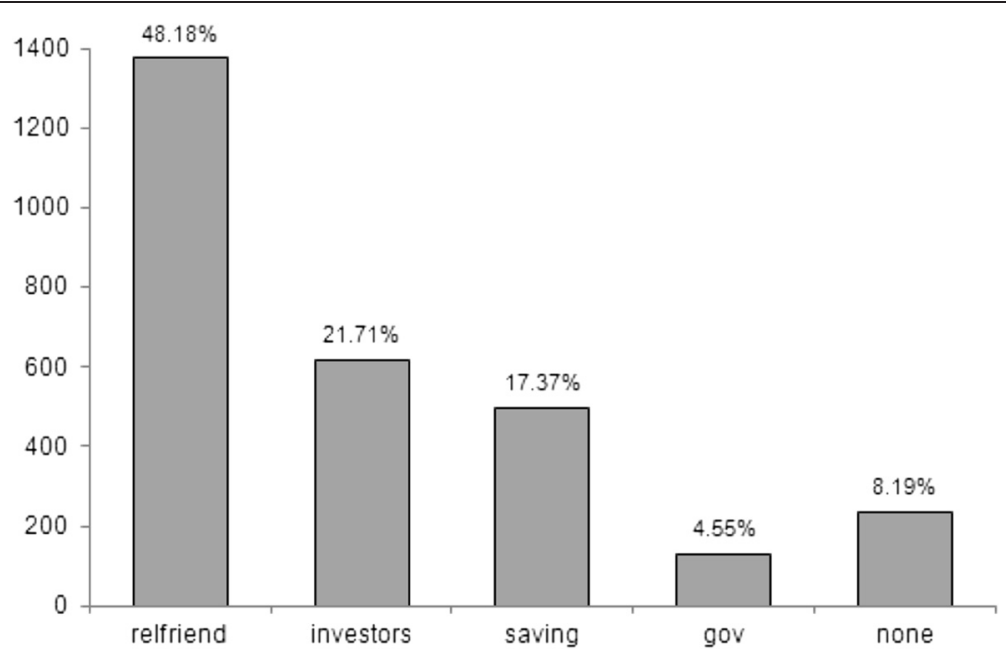

Fig. 3 An indication of key source of finance for Vietnamese entrepreneurs

Out of 2524 observations, 1047 face issues of financial constraints ( 41.48\%), and 1477 do not think they face financial shortage ("noshort") (see Table 1).

The largest portion of entrepreneurs, about $52 \%$, are those who only act upon favorable socioeconomic conditions (1302/2524).

Table 1 (Data for RQ1). Distribution of entrepreneurs following factors of social network membership, having a business plan, facing financial shortage, and decision on entrepreneurial attempt

\begin{tabular}{|c|c|c|c|c|c|c|}
\hline \multirow{2}{*}{ "member" } & \multirow{2}{*}{ "plan" } & \multirow{2}{*}{ "finance" } & \multicolumn{4}{|c|}{ "startplan" } \\
\hline & & & "a" & "b" & "c" & "d" \\
\hline \multirow{8}{*}{ "no" } & \multirow{2}{*}{ "basic" } & "noshort" & 17 & 62 & 89 & 36 \\
\hline & & "shortage" & 14 & 26 & 50 & 13 \\
\hline & \multirow{2}{*}{ "good" } & "noshort" & 15 & 13 & 15 & 8 \\
\hline & & "shortage" & 11 & 10 & 15 & 8 \\
\hline & \multirow{2}{*}{ "inprocess" } & "noshort" & 16 & 50 & 261 & 80 \\
\hline & & "shortage" & 10 & 46 & 191 & 35 \\
\hline & \multirow{2}{*}{ "noneed" } & "noshort" & 4 & 16 & 60 & 64 \\
\hline & & "shortage" & 2 & 2 & 45 & 24 \\
\hline \multirow{8}{*}{ "yes" } & \multirow{2}{*}{ "basic" } & "noshort" & 37 & 80 & 92 & 22 \\
\hline & & "shortage" & 27 & 43 & 70 & 7 \\
\hline & \multirow{2}{*}{ "good" } & "noshort" & 48 & 38 & 22 & 8 \\
\hline & & "shortage" & 44 & 37 & 35 & 9 \\
\hline & \multirow{2}{*}{ "inprocess" } & "noshort" & 24 & 62 & 155 & 30 \\
\hline & & "shortage" & 17 & 54 & 164 & 17 \\
\hline & \multirow{2}{*}{ "noneed" } & "noshort" & 5 & 7 & 23 & 18 \\
\hline & & "shortage" & 0 & 3 & 15 & 3 \\
\hline
\end{tabular}




\section{Data for RQ2}

The dependent (response) variables for this RQ2 are having the same meaning as described in the data for RQ1. The other factors are as follows.

\begin{tabular}{|c|c|c|}
\hline Factors & Categories & Remarks \\
\hline "chance" & $\begin{array}{l}\text { - "high" } \\
\text { - "med" } \\
\text { • "low" }\end{array}$ & $\begin{array}{l}\text { Independent multinomial variables that reflect self-reported chance of success/survival } \\
\text { of the entrepreneur, having categorical values of "high" (>80\%), "med" (50-80\%), and } \\
\text { low (<50\%). }\end{array}$ \\
\hline "tot1strev" & $\begin{array}{l}\text { - "now" } \\
\text { • "soon" } \\
\text { • "notsure" }\end{array}$ & $\begin{array}{l}\text { Independent polytomous variables that capture estimated waiting time to the first } \\
\text { revenue for venture, having categorical value of "now" (currently generating business } \\
\text { revenues), "soon" (is going to generate revenues within the next } 12 \text { months), and } \\
\text { "notsure" (uncertain about the capability of revenue generation). }\end{array}$ \\
\hline
\end{tabular}

The second data set has $N=2739$, and its tabulated form is given in Table 2 .

About $52 \%$ of respondents expect to be able to generate the first revenue dollar within the next 12 months (1423/2739).

Table 2 (Data for RQ2). Distribution of entrepreneurs following factors of chance of survival, time to the first revenue, and entrepreneurial decision

\begin{tabular}{llllll}
\hline \multirow{2}{*}{ "tot1strev" } & "chance" & "startplan" & & & \\
\cline { 2 - 5 } & "a" & "b" & "c" & 15 \\
\hline \multirow{3}{*}{ "now" } & "high" & 70 & 33 & 47 & 4 \\
& "low" & 12 & 8 & 11 & 18 \\
& "med" & 55 & 37 & 70 & 41 \\
"soon" & "high" & 69 & 149 & 199 & 21 \\
& "low" & 18 & 34 & 78 & 67 \\
& "med" & 87 & 258 & 402 & 65 \\
& "high" & 6 & 43 & 186 & 58 \\
& "low" & 4 & 14 & 107 & 84 \\
\hline
\end{tabular}

\section{Data for RQ3}

For RQ3, the response variables are "tot1strev" as described in the data for RQ2. Two other factors entering the estimations are "job" and "starthis", explained below.

\begin{tabular}{|c|c|c|}
\hline Factors & Categories & Remarks \\
\hline "job" & $\begin{array}{l}\cdot \text { •"none" } \\
\text { • "admin" } \\
\text { • "hrm" } \\
\text { • "fin" } \\
\text { • "pom" } \\
\text { • "salesm" }\end{array}$ & $\begin{array}{l}\text { Independent multinomial variables that indicate past work experiences: "admin" } \\
\text { (general administrative), "hrm" (human resources management), "fin" (finance/ } \\
\text { accounting), "pom" (production and operations management), "salesm" (sales } \\
\text { and marketing functions), and "none" (no previous work experience). }\end{array}$ \\
\hline "starthis" & $\begin{array}{l}\text { - "running" } \\
\text { - "dropped" } \\
\text { • "notyet" }\end{array}$ & $\begin{array}{l}\text { Independent multinomial variables that tell whether the entrepreneur is running } \\
\text { an entrepreneurial firm ("running"), used to operate some venture ("dropped"), } \\
\text { or has never ever started/operated an entrepreneurial venture ("notyet"). }\end{array}$ \\
\hline
\end{tabular}

This set has $N=2722$, provided in Table 3 . About $28 \%$ of the extant/prospective entrepreneurs report to have not had previous work experience $(753 / 2722)$. 
Table 3 (Data for RQ3). Distribution of entrepreneurs following factors of past work experience, past entrepreneurial attempt, and time taken to the first business revenue

\begin{tabular}{|c|c|c|c|c|}
\hline \multirow{2}{*}{ "job" } & \multirow{2}{*}{ "starthis" } & \multicolumn{3}{|c|}{ "tot1strev" } \\
\hline & & "now" & "soon" & "notsure" \\
\hline & "dropped" & 13 & 154 & 115 \\
\hline \multirow[t]{3}{*}{ "admin" } & "notyet" & 10 & 96 & 108 \\
\hline & "running" & 27 & 48 & 18 \\
\hline & "dropped" & 12 & 55 & 24 \\
\hline \multirow[t]{3}{*}{ "finance" } & "notyet" & 2 & 33 & 16 \\
\hline & "running" & 32 & 36 & 9 \\
\hline & "dropped" & 9 & 52 & 16 \\
\hline \multirow[t]{3}{*}{ "hrm" } & "notyet" & 6 & 31 & 18 \\
\hline & "running" & 31 & 37 & 2 \\
\hline & "dropped" & 9 & 149 & 159 \\
\hline \multirow[t]{3}{*}{ "none" } & "notyet" & 8 & 138 & 232 \\
\hline & "running" & 18 & 29 & 11 \\
\hline & "dropped" & 10 & 78 & 26 \\
\hline \multirow[t]{3}{*}{ "pom" } & "notyet" & 7 & 36 & 12 \\
\hline & "running" & 55 & 71 & 5 \\
\hline & "dropped" & 25 & 179 & 96 \\
\hline \multirow[t]{2}{*}{ "salesm" } & "notyet" & 12 & 66 & 57 \\
\hline & "running" & 92 & 114 & 18 \\
\hline
\end{tabular}

It is noteworthy that 232/753 respondents do not have either work or entrepreneurial experiences in the past and they are uncertain about when their business ventures will be able to generate a first revenue.

Data for RQ4

For RQ4, the response variables are the same "tot1strev" as described in the data for RQ2 and RQ3. Other factors are described below.

\begin{tabular}{|c|c|c|}
\hline Factors & Categories & Remarks \\
\hline "mres" & $\begin{array}{l}\text { • "none" } \\
\text { - "saving" } \\
\text { - "relfriends" } \\
\text { - "gov" } \\
\text { - "investors" }\end{array}$ & $\begin{array}{l}\text { Independent multinomial variables that indicate past work experiences: "admin" } \\
\text { (general administrative), "hrm" (human resources management), "fin" (finance/ } \\
\text { accounting), "pom" (production and operations management), "salesm" (sales } \\
\text { and marketing functions), and "none" (no previous work experience). }\end{array}$ \\
\hline "tforstart" & $\begin{array}{l}\text { • "g24" } \\
\text { • "less24" }\end{array}$ & $\begin{array}{l}\text { Independent dichotomous variables that indicates entrepreneur's perseverance } \\
\text { with his/her commitment to this entrepreneurial attempt: on a long-term basis } \\
\left.\text { ("g24") or shot-term basis ("less } 24^{\prime \prime}\right) \text {. }\end{array}$ \\
\hline
\end{tabular}

Using the financial constraint factor as the control variate, Table 4 provides a data subset for 1044 (of $N=2722$ ) with financial constraints.

Among the subset of 1044, 751 report that they will be highly committed to their entrepreneurial firms. Of these, 185 assess that they will receive resources from relatives/friends and their firms are likely to generate revenues within the next 12 months. Likewise, Appendix 1 provides the data subset for those without financial constraints. 
Table 4 (Data for RQ4). Distribution of financially constrained entrepreneurs following factors of perseverance, resources, and time taken to the first business revenue

\begin{tabular}{lllll}
\hline \multirow{2}{*}{ "tforstart" } & "mres" & "tot1strev" & & "soon" \\
\cline { 3 - 5 } & "gow" & 15 & 16 \\
\hline \multirow{2}{*}{ "g24" } & "investors" & 1 & 91 & 42 \\
& "none" & 19 & 16 & 37 \\
& "relfriends" & 4 & 185 & 160 \\
& "saving" & 46 & 47 & 43 \\
& "gov" & 29 & 11 & 4 \\
& "Invess24" & 4 & 37 & 8 \\
& "none" & 9 & 5 & 7 \\
& "relfriends" & 1 & 92 & 32 \\
\hline
\end{tabular}

\section{Estimations and results}

\section{Estimations and results for $R Q 1$}

Most of estimated coefficients are statistically significant at the conventional level, and $15 / 18$ are highly significant with $p<0.01$. Details of estimations are provided in Table 5 . The general trend shows that "wait-and-see" mentality appears to have been predominant in the society.

Table 5 Estimation results for $\mathrm{RQ} 1$

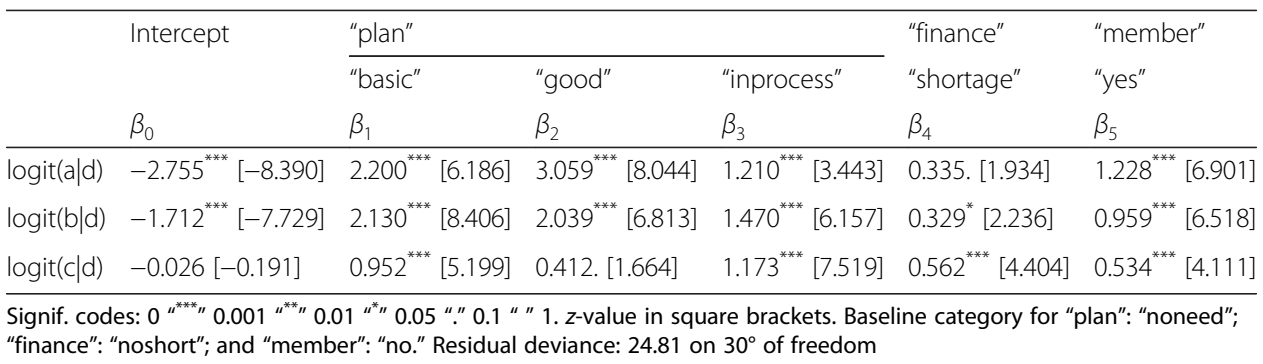

The single largest coefficient in Table 5 is $\beta_{2}=3.059(p<0.0001)$, supporting the idea that having a good business plan increases the chance of an entrepreneur currently operating an entrepreneurial firm. The following relationships (RQ1.1-1.3) are derived from Table 5.

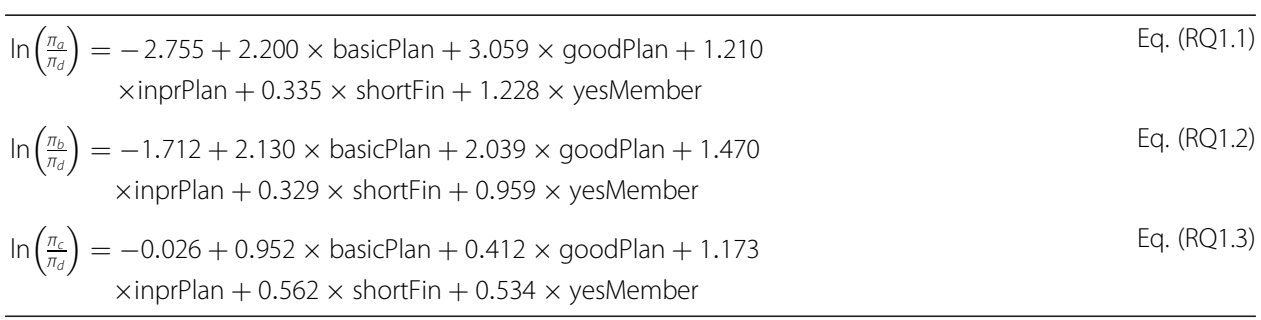

Reading Eq. (RQ1.3) gives an understanding that having no business plan (i.e., unpreparedness) the entrepreneur tends to wait for "favorable conditions" to decide a start of his/her venture. In fact, $\beta_{3}=1.173(p<0.0001)$ is the largest in the equation and indicates 
that having no plan is the most influential factor for the decision of waiting for better conditions. From these relationships, Table 6 provides computed empirical probabilities of entrepreneurship decisions based on financial conditions and preparedness.

Examples of computing a specific probability of Table 6 is given in Appendix 2 (a). Reading a cell of the table is as follows. Take Table 6 (c), $a_{12}=0.383$ indicates that the probability of a financially constrained entrepreneur currently operating a venture is still high, if that person has a high degree of preparedness (with good business plan) and actively participates in social networks of entrepreneurs. Figure 4 shows impacts of preparedness and financial constraints on entrepreneurial decisions for those actively participating in social networks of entrepreneurs, using data from Appendix 3.

\section{Estimations and results for RQ2}

Estimating the data set for RQ yields results provided in Appendix 4. In the similar way to RQ1 in the preceding discussion, the table reports empirical probabilities conditional upon factors of the estimated time to the first revenue and chance of success (Table 7).

Also in this investigation, Fig. 5 using data provided in Appendix 5 and Appendix 6 presents two trends of probabilities of start decisions for the entrepreneurs who estimate a high chance of success/survival.

Figure 5 indicates that those who face uncertainty of the first revenue tend to wait or abandon their entrepreneurial attempts. In contrary, those who see high chance of obtaining the first revenue within the next 12 months are more likely to decide to start earlier.

\section{Estimations and results for $\mathrm{RQ3}$}

Estimated coefficients and corresponding statistics are reported in Table 8, with all showing statistical significance at conventional levels $(p<0.1)$.

Table 6 Probability distributions of entrepreneurial decision over preparedness, financial constraints, and participations in social networks

\begin{tabular}{|c|c|c|c|c|c|c|c|c|}
\hline "startplan" & \multicolumn{4}{|c|}{ "running" (a) } & \multicolumn{4}{|l|}{ "soon" (b) } \\
\hline "member" & \multicolumn{2}{|l|}{ "yes" } & \multicolumn{2}{|l|}{ "no" } & \multicolumn{2}{|l|}{ "yes" } & \multicolumn{2}{|l|}{ "no" } \\
\hline "plan"|"finance" & "shortage" & "noshort" & "shortage" & "noshort" & "shortage" & "noshort" & "shortage" & "noshort" \\
\hline "basic" & 0.163 & 0.175 & 0.096 & 0.102 & 0.328 & 0.353 & 0.253 & 0.270 \\
\hline "good" & 0.383 & 0.394 & 0.256 & 0.260 & 0.298 & 0.308 & 0.260 & 0.266 \\
\hline "inprocess" & 0.071 & 0.080 & 0.038 & 0.041 & 0.199 & 0.224 & 0.138 & 0.153 \\
\hline "noneed" & 0.062 & 0.065 & 0.029 & 0.029 & 0.134 & 0.141 & 0.082 & 0.081 \\
\hline "startplan" & \multicolumn{4}{|c|}{ "only with favorable conditions" (c) } & \multicolumn{4}{|c|}{ "not to start" (d) } \\
\hline "member" & \multicolumn{2}{|l|}{ "yes" } & \multicolumn{2}{|l|}{ "no" } & \multicolumn{2}{|l|}{ "yes" } & \multicolumn{2}{|l|}{ "no" } \\
\hline "plan"|"finance" & "shortage" & "noshort" & "shortage" & "noshort" & "shortage" & "noshort" & "shortage" & "noshort" \\
\hline "basic" & 0.450 & 0.383 & 0.531 & 0.449 & 0.059 & 0.089 & 0.120 & 0.179 \\
\hline "good" & 0.260 & 0.213 & 0.349 & 0.282 & 0.059 & 0.085 & 0.135 & 0.192 \\
\hline "inprocess" & 0.659 & 0.587 & 0.698 & 0.612 & 0.071 & 0.109 & 0.126 & 0.194 \\
\hline "noneed" & 0.598 & 0.496 & 0.561 & 0.439 & 0.206 & 0.298 & 0.328 & 0.451 \\
\hline
\end{tabular}



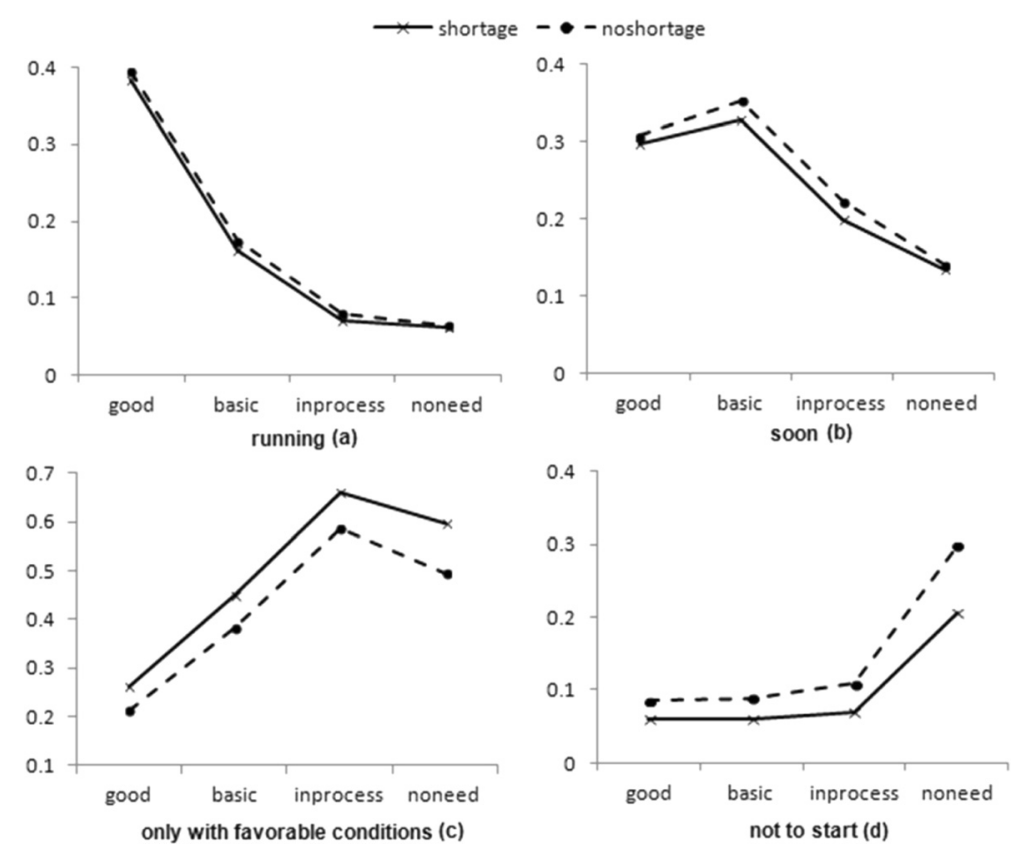

Fig. 4 a-d Changing probabilities of start decisions following business plan preparedness and financial constraints (control variate: active membership in social networks)

Both past work experiences and previous entrepreneurial attempts have influence on the time lag to the first revenue. Specifically, their empirical relationships are given in Eqs. (RQ3.1-2), drawn upon coefficients from Table 8.

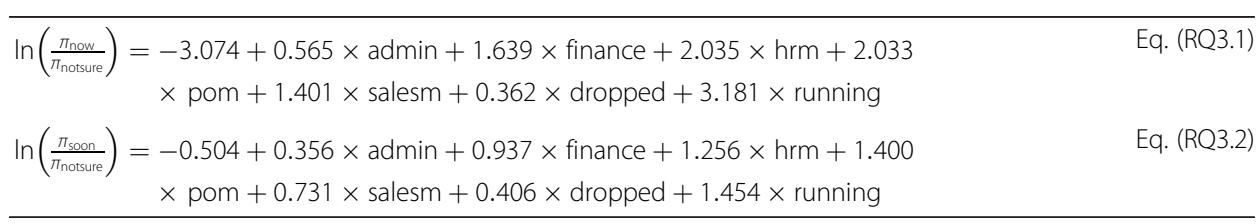

From Eq. (RQ3.2), the fact that the coefficient for "running" with $\beta_{7}=1.454(p<0.0001)$ is telling: only entrepreneurs currently operating a venture can be more realistic and confident about their chance of generating revenues within the next 12 months. Also, from Eqs.(RQ3.1-3.2), empirical probabilities are computed and provided in Table 9.

Table 7 Probability distributions of decisions over time to the first revenue and chance of success

\begin{tabular}{|c|c|c|c|c|c|c|c|c|c|c|c|c|}
\hline \multirow{2}{*}{$\begin{array}{l}\text { "startplan" } \\
\text { "tot1strev"|"chance" }\end{array}$} & \multicolumn{3}{|c|}{ "running" (a) } & \multicolumn{3}{|c|}{ "soon" (b) } & \multicolumn{3}{|c|}{$\begin{array}{l}\text { "only with favorable } \\
\text { conditions" (c) }\end{array}$} & \multicolumn{3}{|c|}{ "not to start" (d) } \\
\hline & "low" & "med" & "high" & "low" & "med" & "high" & "low" & "med" & "high" & "low" & "med" & "high" \\
\hline "now" & 0.349 & 0.315 & 0.413 & 0.157 & 0.211 & 0.209 & 0.340 & 0.381 & 0.288 & 0.154 & 0.093 & 0.090 \\
\hline "soon" & 0.125 & 0.105 & 0.152 & 0.245 & 0.307 & 0.336 & 0.485 & 0.506 & 0.424 & 0.145 & 0.082 & 0.088 \\
\hline "notsure" & 0.016 & 0.015 & 0.024 & 0.074 & 0.102 & 0.122 & 0.606 & 0.695 & 0.635 & 0.304 & 0.188 & 0.219 \\
\hline
\end{tabular}




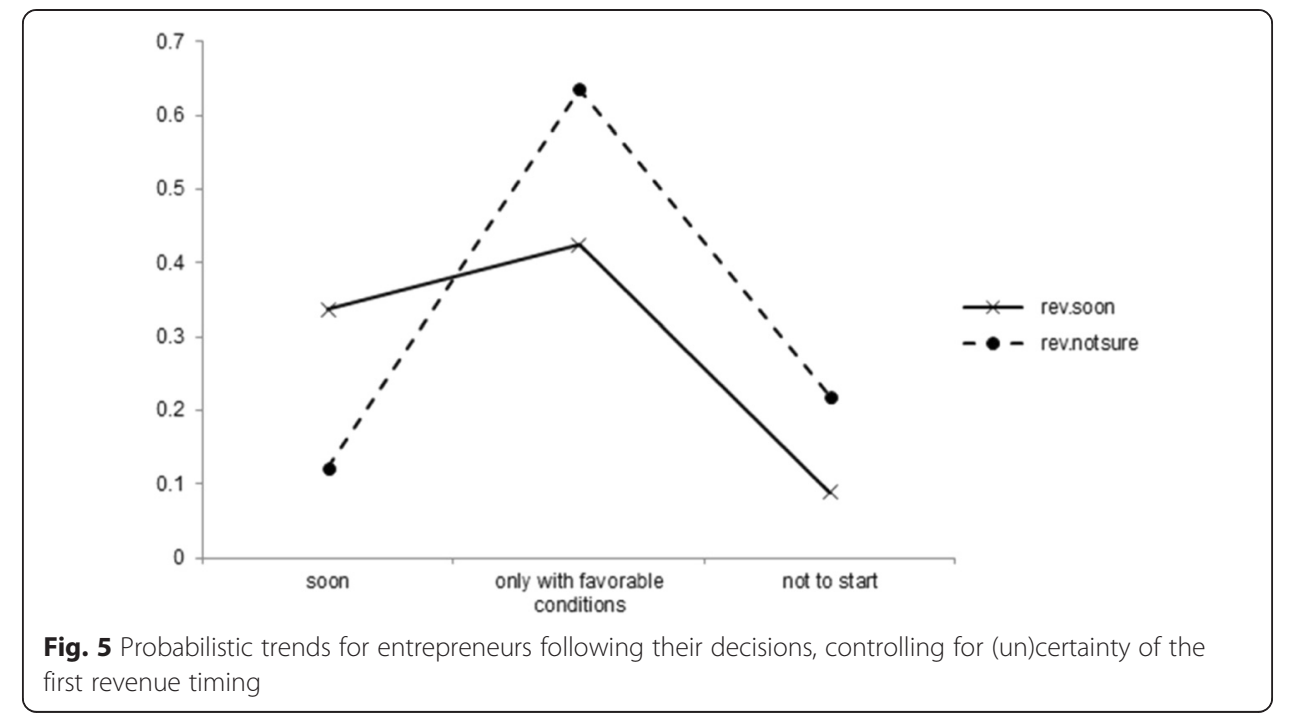

\section{Estimations and results for RQ4}

Table 10 provides estimated impacts of resources/supports and perseverance on the time required to the first revenue, for financially constrained entrepreneurs.

In these estimations, both factors of resources and perseverance have significant influence. They are better interpreted with relationships reflected by Eqs. (RQ4.1-4.2) and then computed probabilities showing relationships among the time taken for having the first revenue and entrepreneurs' perseverance and types of resources (Table 11).

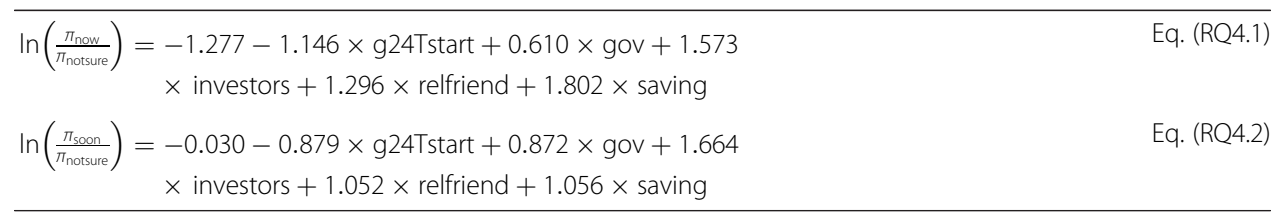

In addition, using computed values in Appendix 7, Fig. 6 presents the impacts of perseverance and types of resources for those financially constrained.

For those without financial constraints, detailed computations are presented in Appendix 8. Conditional probabilities following Appendix 8 are in Table 12.

Table 8 Estimations for RQ3

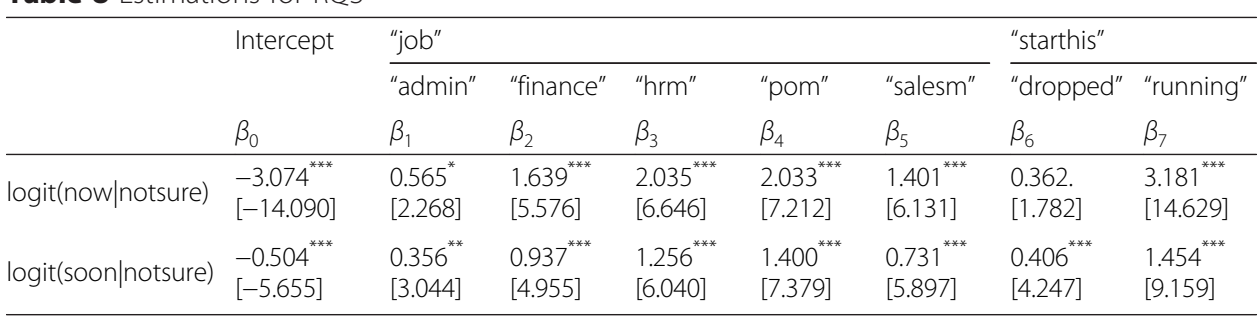

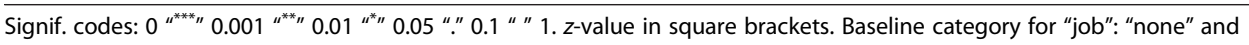
"starthis": "notyet." Residual deviance: 15.38 on 20 d.f. 
Table 9 Probabilities of time to the first revenue following past work and entrepreneurial experiences

\begin{tabular}{|c|c|c|c|c|c|c|c|c|c|}
\hline \multirow{2}{*}{$\begin{array}{l}\text { "tot1strev" } \\
\text { "starthis"| } \\
\text { "job" }\end{array}$} & \multicolumn{3}{|l|}{ "now" (a) } & \multicolumn{3}{|l|}{ "soon" (b) } & \multicolumn{3}{|c|}{ "notsure" (c) } \\
\hline & "running" & "dropped" & "notyet" & "running" & "dropped" & "notyet" & "running" & "dropped" & "notyet" \\
\hline "admin" & 0.294 & 0.048 & 0.042 & 0.555 & 0.537 & 0.444 & 0.151 & 0.415 & 0.514 \\
\hline "finance" & 0.430 & 0.094 & 0.086 & 0.495 & 0.633 & 0.555 & 0.075 & 0.273 & 0.359 \\
\hline "hrm" & 0.458 & 0.108 & 0.102 & 0.488 & 0.679 & 0.610 & 0.054 & 0.213 & 0.288 \\
\hline "pom" & 0.425 & 0.098 & 0.093 & 0.525 & 0.709 & 0.644 & 0.050 & 0.193 & 0.263 \\
\hline "salesm" & 0.415 & 0.085 & 0.077 & 0.493 & 0.597 & 0.514 & 0.092 & 0.318 & 0.409 \\
\hline "none" & 0.237 & 0.034 & 0.028 & 0.550 & 0.460 & 0.366 & 0.213 & 0.506 & 0.606 \\
\hline
\end{tabular}

Comparing probabilities from Tables 11 (a) and 12 (a) shows that the financially unconstrained tend to take advantage of government resources better than the financially constrained. Figure 7 also gives trends for comparing the financially constrained and unconstrained for other types of resource, except from the government (details in Appendix 9).

\section{Conclusions}

In this final part, we offer some key insights learned from the reported results.

\section{The matter of time}

In line with results from RQ1, such factors as preparedness, availability of financial resources, and participation in social networks of entrepreneurs all have significant effects on entrepreneurial decision, especially as far as concrete timing is concerned. Although there are plenty of "ideas" shared and discussed within the community, it is not obvious for one to reach the decision of pursuing a business venture. That is why sharing knowledge and plan with an entrepreneurs' community has the effect of strengthening the ideation of one's entrepreneurial endeavor, thus contributing to reducing the empirical probabilities of "waiting for favorable conditions"-a vague perception that usually hinders the actual entrepreneurial undertaking.

Entrepreneurs with better business plans show the trend of starting earlier, and the trend holds for both the financially constrained and unconstrained. It is interesting to see the differences in predominant trends among groups of entrepreneurs: (a) those with good plans also tend to be operating a venture (Fig. 4a); (b) those with basic plans are planning to start a venture shortly (Fig $4 \mathrm{~b}$ ); (c) those without a plan tend to wait for

Table 10 Estimation results for RQ4 controlling for financially constrained ("shortage")

\begin{tabular}{|c|c|c|c|c|c|c|}
\hline & \multirow[t]{2}{*}{ Intercept } & \multirow{2}{*}{$\begin{array}{l}\text { "tforstart" } \\
\text { "g24" }\end{array}$} & \multicolumn{4}{|l|}{ "mres" } \\
\hline & & & "gov" & "investors" & "relfriends" & "saving" \\
\hline & $\beta_{0}$ & $\beta_{1}$ & $\beta_{2}$ & $\beta_{3}$ & $\beta_{4}$ & $\beta_{5}$ \\
\hline logit(now|notsure) & $\begin{array}{l}-1.277^{*} \\
{[-2.545]}\end{array}$ & $\begin{array}{l}-1.146^{* * *} \\
{[-5.259]}\end{array}$ & $\begin{array}{l}0.610 \\
{[0.878]}\end{array}$ & $\begin{array}{l}1.573^{* *} \\
{[2.956]}\end{array}$ & $\begin{array}{l}1.296^{* *} \\
{[2.626]}\end{array}$ & $\begin{array}{l}1.802^{* * *} \\
{[3.443]}\end{array}$ \\
\hline logit(soon|notsure) & $\begin{array}{l}-0.030 \\
{[-0.101]}\end{array}$ & $\begin{array}{l}-0.879^{* * *} \\
{[-5.108]}\end{array}$ & $\begin{array}{l}0.872^{*} \\
{[2.152]}\end{array}$ & $\begin{array}{l}1.664^{* * *} \\
{[5.248]}\end{array}$ & $\begin{array}{l}1.052^{* * *} \\
{[3.692]}\end{array}$ & $\begin{array}{l}1.056^{* *} \\
{[3.246]}\end{array}$ \\
\hline
\end{tabular}


Table 11 Probabilities of the time for the first revenue against perseverance and types of resources, controlling for the financially constrained

\begin{tabular}{|c|c|c|c|c|c|c|}
\hline \multirow{2}{*}{$\begin{array}{l}\text { "tot1 strev" } \\
\text { "mres"|"tforstart" }\end{array}$} & \multicolumn{2}{|c|}{ "now" (a) } & \multicolumn{2}{|c|}{ "soon" (b) } & \multicolumn{2}{|c|}{ "notsure" (c) } \\
\hline & "g24" & "less24" & "g24" & "less24" & "g24" & "less24" \\
\hline "gov" & 0.077 & 0.134 & 0.453 & 0.605 & 0.470 & 0.261 \\
\hline "investors" & 0.120 & 0.180 & 0.598 & 0.686 & 0.282 & 0.134 \\
\hline "relfriends" & 0.131 & 0.212 & 0.466 & 0.579 & 0.403 & 0.209 \\
\hline "saving" & 0.199 & 0.308 & 0.430 & 0.509 & 0.371 & 0.183 \\
\hline "none" & 0.059 & 0.124 & 0.270 & 0.431 & 0.671 & 0.445 \\
\hline
\end{tabular}

better conditions to decide (Fig. 4c); and (d) those who do not believe in the value of a business plan are less likely to pursue a real-world venture (Fig. 4d).

Financial constraints have a profound impact on the entrepreneurial decisions. For prospective entrepreneurs (who are not running an entrepreneurial venture), the availability of finance becomes a determining factor in increasing the probabilities of the decision to start soon and not to start for both those who are financially constrained and unconstrained. The difference between the two groups of the constrained and unconstrained can be seen clearly only when looking at the "waitand-see" factor, in which case financial shortage tends to increase the probabilities of waiting.

\section{Chance of success}

Studying RQ2 with Table 7 (a) shows a higher perceived likelihood of success tends to prompt a prospective entrepreneur to act on his ideas. In addition, when one assesses that the time taken to generate the first revenue from business is longer, one would likely delay his decision-making process to see if "favorable" conditions emerge and improve one's chance. Also, empirical computations indicate that there

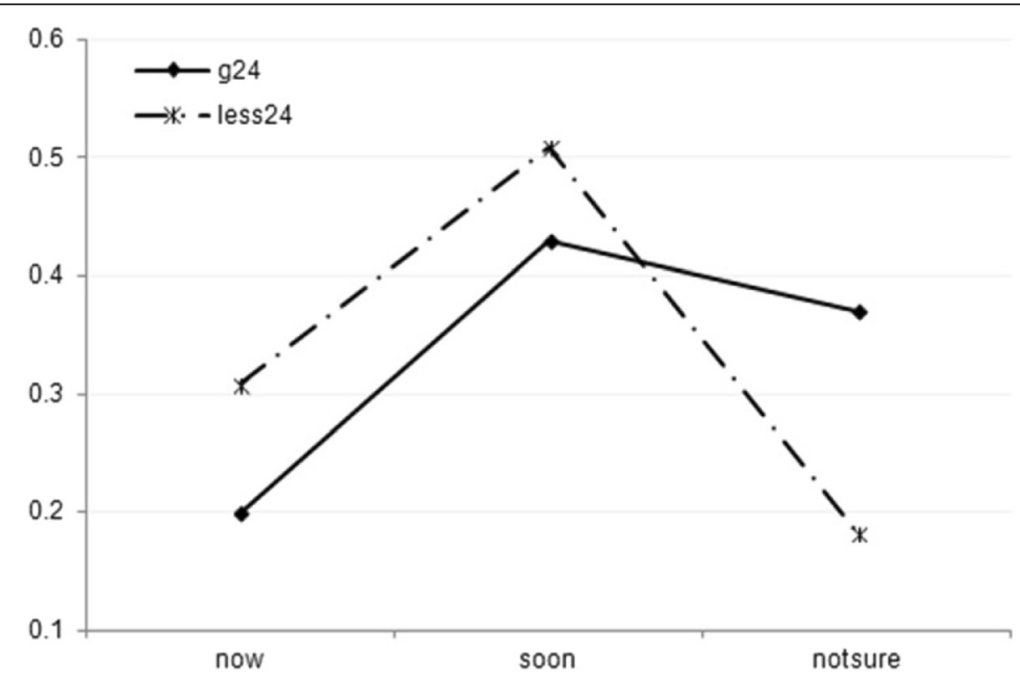

Fig. 6 Probability distributions for event "time lag to the first revenue" for the financially constrained using personal saving as the main type of resource for the entrepreneurial endeavor 
Table 12 Probabilities of the time taken to the first revenue conditional on types of resource and perseverance, controlling for the financially unconstrained ("noshort")

\begin{tabular}{|c|c|c|c|c|c|c|}
\hline \multirow{2}{*}{$\begin{array}{l}\text { "tot1strev" } \\
\text { "mres"|"tforstart" }\end{array}$} & \multicolumn{2}{|c|}{ "now" (a) } & \multicolumn{2}{|c|}{ "soon" (b) } & \multicolumn{2}{|c|}{ "notsure" (c) } \\
\hline & "g24" & "less24" & "g24" & "less24" & "g24" & "less24" \\
\hline "gov" & 0.156 & 0.145 & 0.464 & 0.707 & 0.380 & 0.148 \\
\hline "investors" & 0.115 & 0.092 & 0.630 & 0.823 & 0.255 & 0.085 \\
\hline "relfriends" & 0.125 & 0.125 & 0.421 & 0.686 & 0.454 & 0.189 \\
\hline "saving" & 0.187 & 0.178 & 0.427 & 0.667 & 0.386 & 0.155 \\
\hline "none" & 0.091 & 0.112 & 0.280 & 0.564 & 0.629 & 0.324 \\
\hline
\end{tabular}

is a $41.3 \%$ probability that an extant entrepreneur who is generating revenue sees high chance of success (Table 7, following computations demonstrated in Appendix 2 (b)). This is not obvious as when and how to make money in the real world continue to be an elusive factor for many extant and prospective entrepreneurs. Still, results obtained from the investigation of RQ1 suggest that the "wait-and-see" mentality dominates the entrepreneurs' community as empirical probabilities indicate that even in the cohort of entrepreneurs who see higher chance of success/survival for their entrepreneurial endeavors with expectation of generating revenues within 12 months from the start, they are more likely to wait for "favorable conditions" than to start a venture.

\section{Money matters}

In studying RQ3, the relationship between past work experience and past entrepreneurial attempt is confirmed by results in Table 9. The highest probability found in the table is $70.9 \%$ representing the chance of obtaining the first revenue in a short time span for those who used to make past entrepreneurial efforts, having work experiences in the area of production and operations management (for an example of actual computations, see Appendix 2 (c)).

The likelihood of making money in a short time span for those without work experience or non-business-related experiences such as pure admin work is found to be low
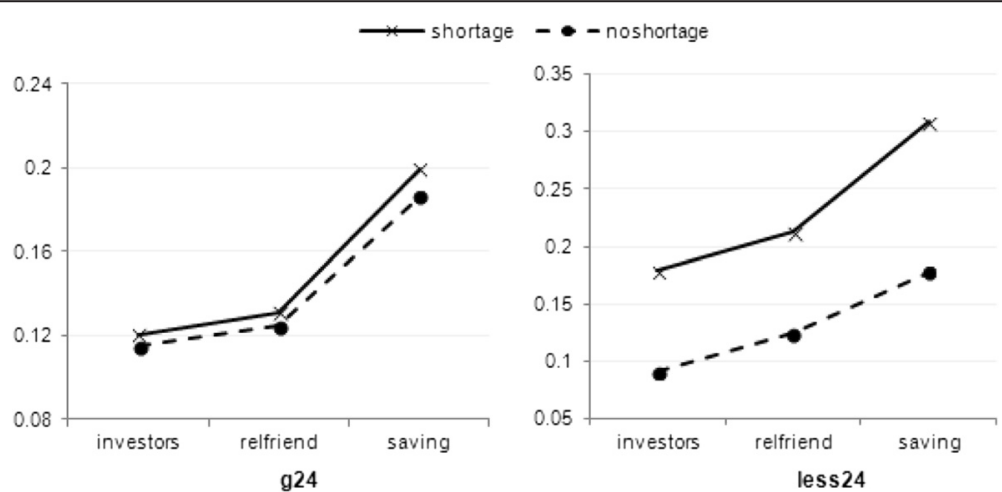

Fig. 7 Probabilistic trends for entrepreneurs with and without financial constraints, controlling for degree of perseverance 
(see Table 9), especially if they have not attempted to pursue a business or dropped their plans.

Overall, work and entrepreneurship experiences have been important to the chance of making early money, which in turn influence the decisiveness of entrepreneurs to start their venture, as indicated by results of RQ1. Prospective entrepreneurs who pursue their endeavors based on wishful thinking, without professional knowledge, skills, and entrepreneurship experiences, would likely face much higher uncertainty of revenue and finally find it less motivating to start. Those who pursue despite all these signs of disadvantages do so at their perils.

\section{The financially constrained vs. unconstrained}

With this consideration, RQ4 connects empirical observations in previous findings to learn about differences in assessment of the time to first revenue for two groups characterized by degree of financial constraints. The results indicate that both perseverance and types of resource have significant impacts on the time lag to the first business revenue, with the resource from saving being the most influential for those who currently have business revenue $\left(\beta_{5}=1.802 ; p<0.001\right)$. This is in line with Harrison's idea about the core value of progressive cultures where saving is the mother of future investments and financial sustainability. In addition, for those who expect to generate revenues soon enough (within 12 months), resources from investors and bankers have the strongest influence $\left(\beta_{3}=1.664 ; p<0.001\right)$.

Also, results from Table 11 suggest that it is impossible to replace the required resources for doing business with time and perseverance without adversely affecting the efficiency of generating revenues (in terms of time). It is because the financially constrained show a low probability of making early money, roughly $6 \%$ (based on computation provided in Appendix 2 (9(b))).

Strikingly, Fig. 2 tells another interesting result. First, the financially constrained appear to have started earlier and shown higher chance of obtaining business revenues from their venture. Second, in case the financially constrained do not expect early revenues, they tend to exercise better perseverance than the unconstrained.

\section{Limitations of the study}

As mentioned earlier, this research is not without limitations. Firstly, although among 3071 respondents a significant portion have come from both urban and rural areas, much of them have been influenced by the environmental factors that are typically of the urban settings, so a generalization of the results for rural and, perhaps, other lagging regions is limited. Secondly, as discussed in the literature review section, the results obtained from this course of research may not have reflected a number of other important and salient features that entrepreneurships and entrepreneurs are hypothetically possessing such as entrepreneurial creativity, effects of information asymmetry, and spatial differences and heterogeneity among groups of different socioeconomic status. This limitation will certainly require further data sampling effort and perhaps more modeling work involving hierarchical data analysis. 


\section{Appendixes}

\section{Appendix 1}

Table 13 (Data for RQ4). Distribution of the financially unconstrained against perseverance, types of resources, and time lag to the first business revenue

\begin{tabular}{lllll}
\hline \hline & "tforstart" & "tot1strev" & & "soon" \\
\cline { 3 - 5 } & & "now" & 26 & 21 \\
\hline "g24" & "gov" & 6 & 143 & 60 \\
& "investors" & 24 & 31 & 62 \\
& "none" & 11 & 218 & 239 \\
& "relfriends" & 65 & 85 & 77 \\
& "less24" & 41 & 12 & 2 \\
& "gaving" & 5 & 107 & 9 \\
& "investors" & 14 & 6 & 8 \\
& "none" & 0 & 121 & 31 \\
& "relfriends" & 22 & 47 & 12 \\
\hline
\end{tabular}

\section{Appendix 2}

Table 14 Examples of empirical probabilities provided in this study

\begin{tabular}{lll}
\hline Table & Place & Actual computations \\
\hline $6(\mathrm{a})$ & $a_{21}$ & $\pi_{a}=\frac{\mathrm{e}^{(-2.755+3.059+0.335+1.228)}}{1+\mathrm{e}^{(-2.755+3.059+0.335+1.228)}+\mathrm{e}^{(-1.712+2.039+0.329+0.959)}+\mathrm{e}^{(-0.026+0.412+0.562+0.534)}}=0.383$ \\
$7(\mathrm{a})$ & $a_{13}$ & $\pi_{a}=\frac{\mathrm{e}^{(-2.219+3.742)}}{1+\mathrm{e}^{(-2.219+3.742)}+\mathrm{e}^{(-0.593+1.436)}+\mathrm{e}^{(1.060+0.104)}}=0.413$ \\
9 (b) & $a_{42}$ & $\pi_{\text {soon }}=\frac{\mathrm{e}^{(-3.074+2.033+0.362)}}{1+\mathrm{e}^{(-3.074+2.033+0.362)}+\mathrm{e}^{(-0.504+1.400+0.406)}}=0.709$ \\
11 (a) & $a_{51}$ & $\pi_{\text {now }}=\frac{\mathrm{e}^{(-1.277-1.146)}}{1+\mathrm{e}^{(-1.277-1.146)}+\mathrm{e}^{(-0.030-0.879)}}=0.059$ \\
\hline
\end{tabular}

\section{Appendix 3}

Table 15 Probabilities of entrepreneurial decisions following preparedness and financial resources of those active in social networks

\begin{tabular}{|c|c|c|c|c|c|c|c|c|}
\hline \multirow{2}{*}{$\begin{array}{l}\text { "startplan" } \\
\text { "plan"|"finance" }\end{array}$} & \multicolumn{2}{|l|}{ "running" } & \multicolumn{2}{|l|}{ "soon" } & \multicolumn{2}{|c|}{$\begin{array}{l}\text { "only with favorable } \\
\text { conditions" }\end{array}$} & \multicolumn{2}{|c|}{ "not to start" } \\
\hline & "shortage" & "noshortage" & "shortage" & "noshortage" & "shortage" & "noshortage" & "shortage" & "noshortage" \\
\hline "basic" & 0.163 & 0.175 & 0.328 & 0.353 & 0.45 & 0.383 & 0.672 & 0.647 \\
\hline "good" & 0.383 & 0.394 & 0.298 & 0.308 & 0.26 & 0.213 & 0.702 & 0.692 \\
\hline "inprocess" & 0.071 & 0.08 & 0.199 & 0.224 & 0.659 & 0.587 & 0.801 & 0.776 \\
\hline "noneed" & 0.062 & 0.065 & 0.134 & 0.141 & 0.598 & 0.496 & 0.866 & 0.859 \\
\hline
\end{tabular}




\section{Appendix 4}

Table 16 Estimating impacts of perceived chance of success and time lag to the first business revenue on entrepreneurial decisions

\begin{tabular}{|c|c|c|c|c|c|}
\hline & Intercept & "tot1strev" & & "chance" & \\
\hline & & "now" & "soon" & "low" & "med" \\
\hline & $\beta_{0}$ & $\beta_{1}$ & $\beta_{2}$ & $\beta_{4}$ & $\beta_{5}$ \\
\hline logit(a|d) & $-2.219^{* * *}[-8.131]$ & $3.742^{* * *}[11.918]$ & $2.770^{* * *}[9.940]$ & $-0.706^{* *}[-2.778]$ & $-0.305 .[-1.734]$ \\
\hline $\operatorname{logit}(b \mid d)$ & $-0.593^{* * *}[-3.814]$ & $1.436^{* * *}[6.085]$ & $1.937^{* * *}[12.095]$ & $-0.823^{* * *}[-3.832]$ & $-0.025[-0.161]$ \\
\hline $\operatorname{logit}(c \mid d)$ & $1.060^{* * *}[9.001]$ & $0.104[0.508]$ & $0.514^{* * *}[4.065]$ & $-0.371^{*}[-2.207]$ & 0.244. [1.822] \\
\hline
\end{tabular}

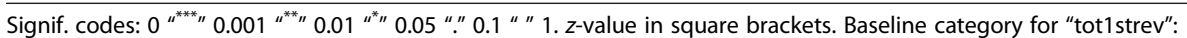

"notsure" and "chance": "high". Residual deviance: 6.639 on 12 d.f.

Stylized relationships derived from the preceding estimation results:

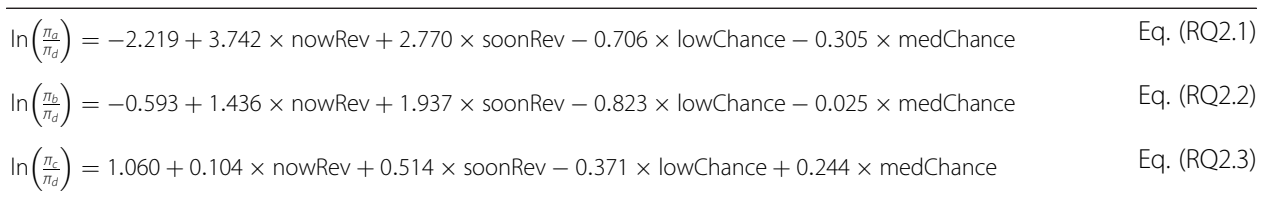

\section{Appendix 5}

Table 17 Probabilities of entrepreneurial decisions following estimated time lag to the first revenue for those with reported higher chance of success/survival

\begin{tabular}{llll}
\hline "tot1strev" & "startplan" & & \\
\cline { 2 - 4 } & "soon" & "only with favorable conditions" & "not to start" \\
\hline "soon" & 0.336 & 0.424 & 0.088 \\
"notsure" & 0.122 & 0.635 & 0.219 \\
\hline
\end{tabular}

\section{Appendix 6}

Table 18 Probabilities of time lag to the first revenue following past entrepreneurial attempts for those with previous finance/accounting experience

\begin{tabular}{llll}
\hline "starthis" & "tot1strev" & & \\
\cline { 2 - 4 } & "now" & "soon" & "notsure" \\
\hline "running" & 0.415 & 0.493 & 0.092 \\
"dropped" & 0.085 & 0.597 & 0.317 \\
"notyet" & 0.077 & 0.514 & 0.409 \\
\hline
\end{tabular}

\section{Appendix 7}

Table 19 Probabilities of time lag to the first revenue following perseverance for the financially constrained, based on type of resource "saving"

\begin{tabular}{llll}
\hline \multirow{2}{*}{ "tforstart" } & "tot1strev" & & \\
\cline { 2 - 4 } & "now" & "soon" & "notsure" \\
\hline "g24" & 0.199 & 0.430 & 0.371 \\
"less24" & 0.308 & 0.509 & 0.182 \\
\hline
\end{tabular}




\section{Appendix 8}

Table 20 Estimating impacts of resource types, perseverance on the time lag to the first revenue for the financially unconstrained

\begin{tabular}{lllllll}
\hline & Intercept & "tforstart" & "mres" & & & \\
\cline { 5 - 7 } & & "g24" & "gov" & "investors" & "relfriends" & "saving" \\
& $\beta_{0}$ & $\beta_{1}$ & $\beta_{2}$ & $\beta_{3}$ & $\beta_{4}$ & $\beta_{5}$ \\
\hline logit(now|notsure) & $-1.069^{* *}$ & $-0.868^{* * *}$ & $1.042^{*}$ & $1.139^{* *}$ & 0.648. & $1.209^{* *}$ \\
& {$[-2.841]$} & {$[-4.054]$} & {$[2.120]$} & {$[2.964]$} & {$[1.860]$} & {$[3.259]$} \\
logit(soon|notsure) & $0.551^{*}[2.213]$ & $-1.362^{* * *}$ & $1.008^{* *}$ & $1.715^{* * *}$ & $0.734^{* *}$ & $0.909^{* * *}$ \\
& & {$[-8.698]$} & {$[2.945]$} & {$[6.846]$} & {$[3.272]$} & {$[3.619]$} \\
\hline
\end{tabular}

Signif. codes: $0{ }^{\prime * * * *} 0.001{ }^{\prime * * *} 0.01{ }^{* * \prime \prime} 0.05$ "." 0.1 " " 1. $z$-value in square brackets. Baseline category for "tforstart": "less $24 "$ and "mres": "none." Residual deviance: 11.64 on 8 d.f.

\section{Empirical relationships:}

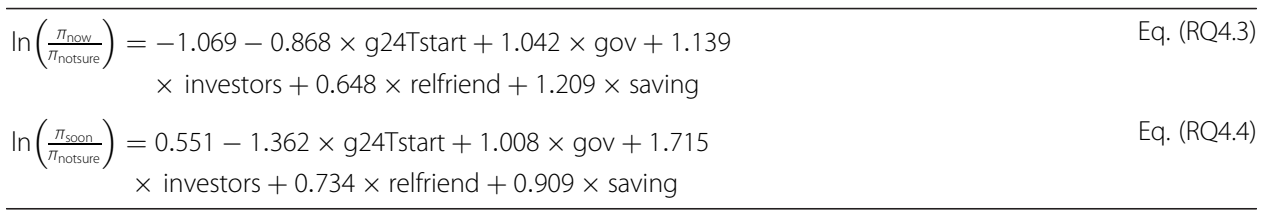

\section{Appendix 9}

Table 21 Probabilities of currently generating revenues the financially constrained ("shortage") and unconstrained ("noshort") on other resource types than government

\begin{tabular}{|c|c|c|c|c|}
\hline \multirow{2}{*}{$\begin{array}{l}\text { "tforstart" } \\
\text { "mres"|"finance" }\end{array}$} & \multicolumn{2}{|l|}{ "g24" } & \multicolumn{2}{|l|}{ "less24" } \\
\hline & "shortage" & "noshortage" & "shortage" & "noshortage" \\
\hline "investors" & 0.120 & 0.115 & 0.180 & 0.092 \\
\hline "relfriends" & 0.131 & 0.125 & 0.212 & 0.125 \\
\hline "saving" & 0.199 & 0.187 & 0.308 & 0.178 \\
\hline
\end{tabular}

\section{Competing interests}

The authors declare that they have no competing interests.

\section{Authors' contributions}

QHV designed the survey, organized the research team, and coordinated the data collecting program. QHV, THD, and TTV prepared, processed, and analyzed the data. QHV interpreted the results and wrote the paper. All the authors read and approved the final manuscript.

\section{Acknowledgements}

We would like to thank the organizers of the entrepreneurs' event for their generous support in collecting the data from participants, especially Trung Nguyen Coffee Group and its "Program for Viet Entrepreneurs' Aspiration," Vietnamese Youth Federation, and Ho Chi Minh City Center for Business Study and Assistance. We are also grateful to the team at Vuong \& Associates for their excellent research assistance, especially Director Dam Thu Ha.

\section{Author details}

${ }^{1}$ Centre Emile Bernheim, Université Libre de Bruxelles, 50 Ave. F.D. Roosevelt, Brussels 1050, Belgium. ²Vuong \& Associates, 3/161 Thinh Quang, Dong Da, Hanoi, Vietnam.

Received: 17 January 2016 Accepted: 23 April 2016

Published online: 03 May 2016 


\section{References}

Agresti, A. (2013). Categorical data analysis (3rd ed.). Hoboken, NJ: Wiley.

Baron, R. A., Franklin, R. J., \& Hmieleski, K. M. (2013). Why entrepreneurs often experience low, not high, levels of stress. The joint effects of selection and psychological capital. Journal of Management. doi:10.1177/0149206313495411.

Bosma, N., Schutjens, V., \& Stam, E. (2009). Determinants of early-stage entrepreneurial activity in European regions; distinguishing low and high ambition entrepreneurship. Making the difference in local, regional and national economies: frontiers in European entrepreneurship research (pp. 49-80).

Brockhaus, R. H. (1980). Psychological and environmental factors which distinguish the successful from the unsuccessful entrepreneur: a longitudinal study. Academy of Management Proceedings, 1, 368-372.

Brown, J. (1993). Entrepreneurship, networks, and modern business. New York, NY: Manchester University Press.

Brush, C. G., Edelman, L. F., \& Manolova, T. S. (2008). The effects of initial location, aspirations, and resources on likelihood of first sale in nascent firms. Journal of Small Business Management, 46(2), 159-182.

Chang, E. P., Memili, E., Chrisman, J. J., Kellermanns, F. W., \& Chua, J. H. (2009). Family social capital, venture preparedness, and start-up decisions: a study of Hispanic entrepreneurs in New England. Family Business Review, 22(3), 279-292.

Chen, C. C., Greene, P. G., \& Crick, A. (1998). Does entrepreneurial self-efficacy distinguish entrepreneurs from managers? Journal of Business Venturing, 13(4), 295-316.

Chen, X. P., Yao, X., \& Kotha, S. (2009). Entrepreneur passion and preparedness in business plan presentations: a persuasion analysis of venture capitalists' funding decisions. Academy of Management Journal, 52(1), 199-214.

Cope, J. (2011). Entrepreneurial learning from failure: an interpretative phenomenological analysis. Journal of Business Venturing, 26(6), 604-623.

Davidsson, P. (2006). Nascent entrepreneurship: empirical studies and developments. Hanover, MA: NOW-Publishers.

Dimov, D. (2010). Nascent entrepreneurs and venture emergence: opportunity confidence, human capital, and early planning. Journal of Management Studies, 47(6), 1123-1153.

Fayolle, A., \& Gailly, B. (2015). The impact of entrepreneurship education on entrepreneurial attitudes and intention: hysteresis and persistence. Journal of Small Business Management, 53(1), 75-93.

Hallak, R., Lindsay, N. J., \& Brown, G. (2011). Examining the role of entrepreneurial experience and entrepreneurial self-efficacy on SMTE performance. Tourism Analysis, 16(5), 583-599.

Hallen, B. L., \& Eisenhardt, K. M. (2012). Catalyzing strategies and efficient tie formation: how entrepreneurial firms obtain investment ties. Academy of Management Journal, 55(1), 35-70.

Hannan, M. T. \& Freeman, J. (1984). Structural inertia and organizational change. American Sociological Review, 49(2), 149-164.

Harris, M. L., \& Gibson, S. G. (2008). Examining the entrepreneurial attitudes of US business students. Education + Training, 50(7), 568-581.

Harris, M. L., Gibson, S. G., \& Taylor, S. R. (2015). Examining the impact of small business institute participation on entrepreneurial attitudes. Journal of Small Business Strategy, 18(2), 57-76.

Harrison, L. E., \& Huntington, S. P. (2000). Culture matters: how values shape human progress. NY: Basic Books.

Huang, L., \& Knight, A. (2015). Resources and relationships in entrepreneurship: an exchange theory of the development and effects of the entrepreneur-investor relationship. Academy of Management Review. doi:10.5465/amr.2014.0397.

Jennings, J. E., \& McDougald, M. S. (2007). Work-family interface experiences and coping strategies: implications for entrepreneurship research and practice. Academy of Management Review, 32(3), 747-760.

Kessler, A., \& Frank, H. (2009). Nascent entrepreneurship in a longitudinal perspective. The impact of person, environment, resources and the founding process on the decision to start business activities. International Small Business Journal, $27(6), 720-742$.

Krueger, N. (1993). The impact of prior entrepreneurial exposure on perceptions of new venture feasibility and desirability. Entrepreneurship: Theory and Practice, 18(1), 5-22.

Kuratko, D. F., Montagno, R. V., \& Hornsby, J. S. (1990). Developing an intrapreneurial assessment instrument for an effective corporate entrepreneurial environment. Strategic Management Journal, 11(5), 49-58.

Lerner, M., Brush, C., \& Hisrich, R. (1997). Israeli women entrepreneurs: an examination of factors affecting performance. Journal of Business Venturing, 12(4), 315-339.

Markman, G. D., Baron, R. A., \& Balkin, D. B. (2005). Are perseverance and self-efficacy costless? Assessing entrepreneurs' regretful thinking. Journal of Organizational Behavior, 26(1), 1-19.

Meyer, J. W., \& Rowan, B. (1977). Institutionalized organizations: formal structure as myth and ceremony. American Journal of Sociology, 83(2), 340-363.

Mollick, E. (2014). The dynamics of crowdfunding: an exploratory study. Journal of Business Venturing, 29(1), 1-16.

Nagy, B. G., Pollack, J. M., Rutherford, M. W., \& Lohrke, F. T. (2012). The influence of entrepreneurs' credentials and impression management behaviors on perceptions of new venture legitimacy. Entrepreneurship: Theory and Practice, 36(5), 941-965.

Santos, S. C., Caetano, A., \& Curral, L. (2013). Psychosocial aspects of entrepreneurial potential. Journal of Small Business \& Entrepreneurship, 26(6), 661-685.

Schindehutte, M., Morris, M., \& Allen, J. (2006). Beyond achievement: entrepreneurship as extreme experience. Small Business Economics, 27(4-5), 349-368

Schoonhoven, C. B., Eisenhardt, K. M., \& Lyman, K. (1990). Speeding products to market: waiting time to first product introduction in new firms. Administrative Science Quarterly, 35(1), 177-207.

Schumpeter, J. A. (1934). The theory of economic development: an inquiry into profits, capital, credit, interest, and the business cycle. Boston, MA: The Fellows and President of Harvard College.

Solymossy, E. (1998). Entrepreneurial dimensions: the relationship of individual, venture, and environmental factors to success. Case Western Reserve University: Doctoral dissertation.

Souitaris, V., Zerbinati, S., \& Al-Laham, A. (2007). Do entrepreneurship programmes raise entrepreneurial intention of science and engineering students? The effect of learning, inspiration and resources. Journal of Business Venturing, 22(4), 566-591.

Sullivan-Taylor, B., \& Branicki, L. (2011). Creating resilient SMEs: why one size might not fit all. International Journal of Production Research, 49(18), 5565-5579. 
Trevelyan, R. (2009). Entrepreneurial attitudes and action in new venture development. The International Journal of Entrepreneurship and Innovation, 10(1), 21-32.

Turker, D., \& Sonmez Selçuk, S. (2009). Which factors affect entrepreneurial intention of university students? Journal of European Industrial Training, 33(2), 142-159.

Valliere, D. (2006). Consequences of growth: shaping entrepreneurial attitudes. The International Journal of Entrepreneurship and Innovation, 7(3), 141-148.

Van de Ven, A. H., Hudson, R., \& Schroeder, D. M. (1984). Designing new business startups: entrepreneurial, organizational, and ecological considerations. Journal of Management, 10(1), 87-108.

Vuong, Q. H. (2015). Be rich or don't be sick: estimating Vietnamese patients' risk of falling into destitution. SpringerPlus, 4(1), 529. doi:10.1186/s40064-015-1279-x.

Vuong, Q. H. (2016). Survey data on entrepreneurs subjective plan and perceptions of the likelihood of success. Data in Brief, 6, 858-864.

Vuong, Q. H., \& Napier, N. K. (2014). Resource curse or destructive creation in transition: evidence from Vietnam's corporate sector. Management Research Review, 37(7), 642-657.

Vuong, Q. H., \& Napier, N. K. (2015). Acculturation and global mindsponge: an emerging market perspective. International Journal of Intercultural Relations, 49, 354-367.

Vyakarnam, S., Jacobs, R., \& Handelberg, J. (1999). Exploring the formation of entrepreneurial teams: the key to rapid growth business? Journal of Small Business and Enterprise Development, 6(2), 153-165.

Wagner, J. (2007). Nascent entrepreneurs. In S. Parker (Ed.), The life cycle of entrepreneurial ventures (pp. 15-37). NY, New York: Springer.

Walstad, W. B., \& Kourilsky, M. L. (1998). Entrepreneurial attitudes and knowledge of black youth. Entrepreneurship: Theory and Practice, 23, 5-18.

Weerawardena, J., \& Mort, G. S. (2006). Investigating social entrepreneurship: a multidimensional model. Journal of World Business, 41(1), 21-35.

Westhead, P., Ucbasaran, D., \& Wright, M. (2009). Information search and opportunity identification: the importance of prior business ownership experience. International Small Business Journal, 27(6), 659-680.

Zahra, S. A., Hayton, J. C., Neubaum, D. O., Dibrell, C., \& Craig, J. (2008). Culture of family commitment and strategic flexibility: the moderating effect of stewardship. Entrepreneurship: Theory and Practice, 32(6), 1035-1054.

Zampetakis, L. A., Kafetsios, K., Bouranta, N., Dewett, T., \& Moustakis, V. S. (2009). On the relationship between emotional intelligence and entrepreneurial attitudes and intentions. International Journal of Entrepreneurial Behavior \& Research, 15(6), 595-618.

Submit your manuscript to a SpringerOpen ${ }^{\circ}$ journal and benefit from:

- Convenient online submission

Rigorous peer review

- Immediate publication on acceptance

- Open access: articles freely available online

- High visibility within the field

- Retaining the copyright to your article

Submit your next manuscript at $>$ springeropen.com 